\title{
Agglomeration and Firm Turnover in Punjab
}

\section{Marjan Nasir*}

\begin{abstract}
The literature on industrial organization shows that geographic and industrial concentration affects firm turnover. This study conducts a firm-level analysis to gauge the impact of agglomeration on firm entry and exit in domestic industries in Punjab, Pakistan. It also illustrates how certain industries exist in clusters while others are highly dispersed. The results suggest that higher rates of firm entry and exit are associated with highly agglomerated industries.
\end{abstract}

Keywords: agglomeration, firm entry, firm exit, Pakistan.

JEL classification: D22, L16.

\section{Introduction}

While the literature on industrial organization has traditionally highlighted the role of new firms as stimulators of economic development, more recent research has focused on the factors affecting the establishment and performance of new firms. Firm entry is associated with employment changes, product and technological innovation and other structural changes in the industry concerned. Furthermore, as incumbent firms face greater competition from new firms, this results in improved productivity, which might otherwise have crowded them out. This paper looks at the effect of agglomeration on firm entry and exit in Punjab's manufacturing sector.

Evidence of industrial agglomeration and the factors causing the geographical concentration of firms in Pakistan has been put forward by Burki and Khan (2010). They show that industries tend to be concentrated in districts with an infrastructure (in the form of road density), access to markets and resources such as skilled labor. Accordingly, new firms are more likely to locate near similar firms to take advantage of positive spillovers in the form of shared resources and knowledge or technological spillovers.

\footnotetext{
* Teaching Fellow, Department of economics, Lahore School of Economics, Pakistan.
} 
The study's aim is to determine why industrial agglomeration tends to attract new businesses. The literature on industrial organization in Pakistan has not studied firm entry and exit rates or their determinants primarily due to insufficient data. This study uses data from the Punjab Directory of Industries, available for 2002, 2006 and 2010, to map selected industries in which firms either exist in clusters or are highly dispersed. It thus aims to contribute to the existing literature by looking at the impact of spatial and industrial concentration on the entry and exit rates of manufacturing firms in Punjab. The results support other studies that have found that firm entry and exit rates are higher in more agglomerated industries.

The literature on firm entry and agglomeration is discussed in Section 2. Section 3 presents a theoretical model, Section 4 describes the data used, which is then mapped in Section 5. The econometric model and results are presented in Sections 6 and 7, respectively. Section 8 concludes the paper.

\section{Literature Review}

Studies in this field have looked at factors that limit or attract the entry of new establishments by analyzing the manufacturing, retail and nonfinancial sectors at the firm or plant level. According to Hopenhayn (1992), firms in the manufacturing sector tend to be replaced by new entrants over five-year periods, with a similar trend in job turnover. The literature on firm entry differentiates between new entrants - also referred to as 'greenfield' firms - and existing or diversifying firms that have set up plants in different geographical areas and/or expanded their range of products.

The importance of studying entry rates lies in their contribution to regional development. Whether these benefits are direct (such as job creation) or indirect (such as improvements in supply conditions), new establishments tend to stimulate economic development. They augment the industry's resource flows (Roberts \& Thompson, 2003) by affecting its productivity and contributing to product and technological innovation. Moreover, these entrants increase competition in the existing market, thus affecting firms' output, pricing and nonpricing decisions. However, Fritsch and Mueller (2004) suggest that these benefits can take as long as eight years to materialize.

Several studies have looked at agglomeration as a source of firm entry and exit, including Devereux, Griffith and Simpson (2004); Dumais, Ellison and Glaeser (2002); Carlton (1983); Rosenthal and Strange (2010); and De Silva and McComb (2011). Their findings suggest that 
agglomeration has a significant impact on the entry of small firms and lowtech firms and on the survival rate of existing firms. New firms or plants are likely to locate near their input suppliers or similar establishments because this allows them to take advantage of positive externalities in the form of labor pooling or technology and knowledge spillovers. These effects vary across industries as well as geographical areas.

In the case of manufacturing plants, Dumais et al. (2002) suggest that firm exit contributes to a decline in industrial concentration while new plant entry leads to firm clustering. This suggests that a region's acquired characteristics, rather than its endowed resources, are an important factor in firm location. Porter (2000) explains that new businesses are more likely to be established within a cluster rather than in a remote area, given lower barriers to entry and exit and because resources such as assets, skills and inputs are more readily available. While this leads to higher entry rates in a cluster, it also means that exit rates remain high because firms require less specialized investment.

The combination of lower entry/exit barriers and greater competition from incumbent firms in that cluster results in higher entry and exit rates for firms in agglomerated industries. Firm survival becomes more difficult, the more agglomerated the industry: the competition from incumbent firms rises as resources become more accessible, together with increasing spillover benefits. However, there is also evidence that agglomeration can have a negative effect on new firm entry - measured by their share of employment - especially for large firms, which seem to be more integrated than small firms. This would suggest that new firms are more likely to locate where there is less geographical concentration of similar firms, although the risk of closure is also more pronounced among these firms.

The Ellison-Glaeser index (EGI) of agglomeration uses the Gini coefficient to measure raw geographical concentration and the Herfindahl index of industrial concentration to determine whether an industry is agglomerated (Ellison \& Glaeser, 1997). The index requires employment data to calculate these ratios: a highly agglomerated industry will have a high, positive value while a low or negative value implies that the industry is dispersed. An intermediate index value points to a moderately agglomerated industry. This paper uses the EGI to measure agglomeration.

\section{Agglomeration and Firm Entry in Domestic Industries}

The theoretical background and model in this section relates agglomeration, through knowledge spillovers, to firm entry, assuming all 
other domestic and foreign factors affecting firm entry are held constant. Marshall (1920) argues that geographical concentration or the clustering of industries enhances learning and the exchange of knowledge among firms. This implies that similar firms will locate near each other to take advantage of these spillovers.

Soubeyran and Thisse (1998), who introduce a formalized model of this notion, look at knowledge spillovers (technological externalities) in districts with agglomerated industrial clusters that have attracted new firms. Knowledge spillovers are acquired through learning-by-doing: workers within a particular geographical boundary are likely to share information and ideas with each other, which eventually increases their productivity as firm employees. The model assumes that labor is immobile between geographic locations such as districts and, therefore, that knowledge spillovers are limited to that geographical area or industrial cluster. Moreover, the higher the stock of knowledge or spillover effects in a cluster, the more attractive the industrial cluster becomes to new firms.

The model developed by Soubeyran and Thisse (1998) comprises a set of locales denoted by $M$, with $x \in M=\{1, \ldots, m\}$. Each locale $x$ in period $t$ has a fixed labor supply $L_{t}^{x}$, an initial stock of knowledge $S_{0}^{x} \geq 0$ and an identical continuum of entrepreneurs who can start a new firm with capital $K_{t}^{x}$ at interest rate $r_{t}$ and sell homogenous goods in the world at price $p_{t}$. There is an infinite number of periods $t=1,2 \ldots$ and entrepreneurs can set up a firm in a new locale in any new period. In order to incorporate Marshallian industrial districts (indicating an agglomerated industrial area), the model assumes that labor will accumulate knowledge over time through different social interactions (the spillover effect). Firms can take advantage of these spillovers only if they locate in $x$. Finally, it assumes that $\ell^{\prime}\left(S_{t-1}^{x}\right)<0$.

The cost function faced by a firm in locale $x$ in period $t$ is given by:

$$
C_{t}^{x}\left(q_{t}^{x}, w_{t}^{x}, S_{t-1}^{x}\right)=w_{t}^{x} \ell\left(S_{t-1}^{x}\right) q_{t}^{x}+r_{t} K\left(q_{t}^{x}\right)
$$

where $q_{t}^{x}$ is output, $w_{t}^{x}$ denotes wages and $S_{t-1}^{x}$ is the sum of past production. The labor coefficient $\ell\left(S_{t-1}^{x}\right)$ takes into account the skills accumulated by workers through knowledge spillovers over time: the more knowledge spillovers, the higher the skills accumulated over time. The amount of capital $K\left(q_{t}^{x}\right)$ required by a new firm is constant across locales.

The profit of a firm established in locale $x$ in period $t$ is denoted by:

$$
\Pi_{t}^{x}\left(q_{t}^{x}, w_{t}^{x}, S_{t-1}^{x}\right)=p_{t} q_{t}^{x}-C_{t}^{x}\left(q_{t}^{x}, w_{t}^{x}, S_{t-1}^{x}\right)
$$


Firms deciding to enter a new locale in period $t$ will maximize their profit $\Pi_{t}^{x}$ with a negligible impact on total industry output. The term $S_{t-1}^{x}$ is the technological externality (knowledge stock) affecting the firms in that locale or industry. Differentiating equation (2) with respect to $S_{t-1}^{x}$ yields the effect of knowledge on the firm's profit:

$$
\frac{\partial \widehat{\Pi}_{t}^{x}}{\partial S_{t-1}^{x}}=-w_{t}^{x} \hat{q}_{t}^{x} \ell^{\prime}\left(S_{t-1}^{x}\right)>0
$$

Equation (3) shows that firm profits in a locale increase with the knowledge stock accumulated therein. The following expression indicates positive production by firms:

$$
\left.\hat{q}_{t}^{x}=\left(K^{\prime}\right)^{-1}\left\{\left[p_{t}-w_{t}^{x} \ell\left(S_{t-1}^{x}\right)\right] / r_{t}\right]\right\}
$$

Given $w_{t}^{x}$ and $S_{t-1}^{x}$, equation (3) is maximized with respect to $q_{t}^{x}$ to obtain:

$$
\frac{\partial \pi_{t}^{x}}{\partial q_{t}^{x}}=P_{t}-w_{t}^{x} \ell\left(S_{-1}^{x}\right)-r_{t} K^{\prime}\left(q_{t}^{x}\right) \leq 0, q_{t}^{x} \frac{\partial \pi_{t}^{x}}{\partial q_{t}^{x}}=0, q_{t}^{x} \geq 0
$$

This partially satisfies the second-order condition. Let $\hat{q}_{t}^{x}$ be the unique solution to equation (5). The following expression indicates positive production by firms:

Combining equations (5) and (2) gives the value function:

$$
\widehat{\Pi}_{t}^{x}=\Pi_{t}^{x}\left[\hat{q}_{t}^{x}\left(w_{t}^{x}, S_{t-1}^{x}, r_{t}, p_{t}\right), w_{t}^{x}, S_{t-1}^{x}\right]=\widehat{\Pi}_{t}^{x}\left(w_{t}^{x}, S_{t-1}^{x}, r_{t}, p_{t}\right)
$$

This can be summarized as:

$$
\widehat{\Pi}_{t}^{x}=r_{t} \lambda\left(\hat{q}_{t}^{x}\right)
$$

Equation (7) denotes the maximum profit a firm can make when set up in locale $x$. This helps determine the equilibrium distribution of firms across locales.

In the model's short-run equilibrium, no firms are set up in $t=0$ and the initial stock of knowledge is $S_{0}^{x} \geq 0$. To maximize profits, firms are set up in locale $x$ in $t=1$ and are attracted to those locales where the stock of knowledge is highest, indicating a more productive labor force. In equilibrium, profits are equal across locales. Given full employment, the number of firms $\left(n_{t}^{x}\right)$ in locale $x$ is: 


$$
n_{t}^{x}=L^{x} / \hat{q}_{t}^{x} \ell\left(S_{t-1}^{x}\right)
$$

The condition that profits are equal across locales, together with equation (8), implies that $r_{t} \lambda\left(\hat{q}_{t}^{x}\right)=r_{t} \lambda\left(\hat{q}_{t}^{y}\right)$ with $x, y \in I_{t}$ (where $I_{t}$ represents the locales in which firms have been established). This shows that firm output in equilibrium is the same across locales. The equilibrium output is denoted by:

$$
\hat{q}_{t}\left(I_{t}\right)=\sum_{x \in M} L^{x} v\left(S_{t-1}^{x}\right) \text {, where } v \text { is strictly increasing }
$$

Combining equations (9) and (8) yields the equilibrium distribution of firms:

$$
n_{t}^{x}\left(I_{t}\right)=\frac{L^{x} v\left(S_{t-1}^{x}\right)}{\sum_{y \in I_{t}} L^{y} v\left(S_{t-1}^{y}\right)^{\prime}}, x \in I_{t}
$$

The interpretation of equation (10) is important: it shows that the higher the stock of labor $(L)$ or knowledge spillovers $(S)$ in locale $I_{t}$, the higher the number of new firms $(n)$ that will locate there.

\section{Data and Descriptive Statistics}

This study uses data from the Directory of Industries compiled by the Punjab government for 2002, 2006 and 2010. It includes approximately 18,000 manufacturing firms - giving the name and address of each - in nearly 180 industries (2-digit) in Punjab. Other information includes the year of establishment, employment and initial investment. The employment data was used to calculate the agglomeration index and determine firm size while initial investment was used as a control factor as a proxy for sunk costs. The industry and firm descriptive statistics are presented in Table 1.

Table 1: Descriptive statistics for all industries, 2006

\begin{tabular}{ll}
\hline Number of industries & 180 \\
Number of firms & 18,007 \\
Mean firm age (years) & 17 \\
Mean number of employees & 48 \\
Mean industry entry rate & 0.10 \\
Mean industry exit rate & 0.25 \\
Mean industry EGI (2002) & 0.1554 \\
Mean industry output growth (percent) & 86 \\
Mean initial investment (PKR '000) & 40,892 \\
\hline
\end{tabular}

Source: Government of the Punjab, Directory of Industries for 2006. 
There were 180 (2-digit) industries comprising 18,007 firms in Punjab in 2006. On average, each firm had been in operation for 17 years and employed around 48 workers. From 2002 to 2006, the mean firm entry rate was 10 percent and the exit rate was 25 percent. On average, the industries had become more agglomerated, as indicated by a positive EGI. Output growth remained high across all industries over this period, with firms undertaking an initial investment of approximately PKR 40 million, on average (with a median value of PKR 2,648,000).

Table 2 lists the top 20 industries in Punjab in descending order of entry, while Table 3 lists the top 20 industries in descending order of exit. Table 4 gives the EGI for the 20 most agglomerated industries.

Table 2: Top 20 industries with the highest entry rates in Punjab, 2006

\begin{tabular}{llc}
\hline Rank & \multicolumn{1}{c}{ Industry } & Entry rate $^{*}$ \\
\hline 1 & Gypsum & 0.93 \\
2 & Mineral water & 0.55 \\
3 & Firefighting equipment & 0.50 \\
4 & Motorcycles/rickshaws & 0.50 \\
5 & Radios/TVs & 0.50 \\
6 & Welding electrodes & 0.50 \\
7 & Zips & 0.50 \\
8 & Knitted textiles & 0.45 \\
9 & Embroidery & 0.43 \\
10 & Cones & 0.43 \\
11 & Doubling of yarn & 0.41 \\
12 & Powder coating & 0.33 \\
13 & Pesticides and insecticides & 0.32 \\
14 & Citrus grading & 0.29 \\
15 & Fruit juices & 0.29 \\
16 & Readymade garments & 0.28 \\
17 & Gas appliances & 0.28 \\
18 & Textile made-ups & 0.28 \\
19 & Ceramics & 0.28 \\
20 & Fertilizer & 0.27 \\
\hline
\end{tabular}

Note: Entry rate in industry $i=$ number of new firms in industry $i$ in 2006 that did not exist in 2002 divided by the total number of firms in industry $i$ in 2006

Source: Government of the Punjab, Directory of Industries for 2006. 
Table 3: Top 20 industries with the highest exit rates in Punjab, 2006

\begin{tabular}{llc}
\hline Rank & \multicolumn{1}{c}{ Industry } & Exit rate $^{*}$ \\
\hline 1 & Bus bodies & 0.99 \\
2 & Nuts and bolts & 0.97 \\
3 & Spices & 0.95 \\
4 & Electroplating & 0.89 \\
5 & Electric furnaces & 0.88 \\
6 & Bakery products & 0.85 \\
7 & Photographic goods & 0.83 \\
8 & Razors/safety razors/blades & 0.83 \\
9 & Dies and blocks & 0.80 \\
10 & Knitted textiles & 0.79 \\
11 & Ice cream & 0.79 \\
12 & Zinc sulfate & 0.75 \\
13 & Bicycles & 0.75 \\
14 & Hand tools & 0.67 \\
15 & Bulbs and tubes & 0.67 \\
16 & Refineries & 0.67 \\
17 & Unani medicines & 0.67 \\
18 & Weights and scales & 0.66 \\
19 & Agricultural implements & 0.64 \\
20 & Pins/clips & 0.60 \\
\hline
\end{tabular}

Note: Exit rate in industry $i=$ number of firms in industry $i$ in 2002 that did not exist in 2006, divided by the total number of firms in industry $i$ in 2002

Source: Government of the Punjab, Directory of Industries for 2006.

Table 4: Top 20 most agglomerated industries in Punjab, 2006

\begin{tabular}{lll}
\hline Rank & \multicolumn{1}{c}{ Industry } & EGI $^{*}$ \\
\hline 1 & Electroplating & 1.5948 \\
2 & Citrus grading & 1.1967 \\
3 & Wool scouring & 1.1652 \\
4 & Powder coating & 1.1072 \\
5 & Musical instruments & 1.0586 \\
6 & Weights and scales & 1.0529 \\
7 & Sports goods & 1.0333 \\
8 & Leather garments & 0.9820 \\
9 & Surgical instruments & 0.9380 \\
10 & Utensils (all sorts) & 0.9254 \\
11 & Belts & 0.9214 \\
12 & Canvas shoes & 0.8583 \\
13 & Raising cloth & 0.8529 \\
14 & Cutlery & 0.8209 \\
15 & Fiber tops & 0.8169 \\
16 & Polyester yarn & 0.8091 \\
17 & Crown corks & 0.7284 \\
18 & Fiberglass & 0.7151 \\
19 & Sanitary fittings & 0.7131 \\
20 & Machine tools & 0.7128 \\
\hline
\end{tabular}

Note: EGI in 2002, measured using employment data.

Source: Government of the Punjab, Directory of Industries for 2006. 


\section{Firm Clustering and Dispersion in Punjab: An Aerial View}

The notion that new firms are likely to locate near similar firms, thus leading to the formation of industrial clusters, can be illustrated using maps. In the first such exercise carried out for Punjab, this study maps eight industries, both clustered and dispersed, using the firm addresses given in the Directory of Industries for 2010.

The number of industrial clusters that have formed in specific areas of Punjab make it easier for incumbent as well as new firms to gain access to resources and technology. On the other hand, we can see that certain industries are completely dispersed and do not comply with the spatial concentration hypothesis presented in the literature. The industries mapped in Figures 1-4 exist as clusters because they require specialized inputs. Those mapped in Figures 5-8 represent industries that are highly dispersed in Punjab.

\section{Figures 1-4: Examples of clustered industries}

Figure 1: Rubber

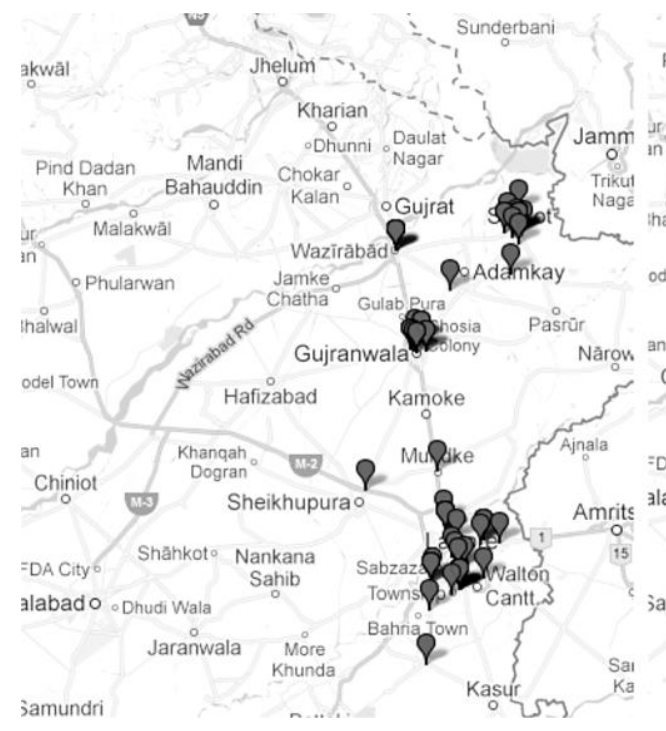

Figure 2: Surgical instruments

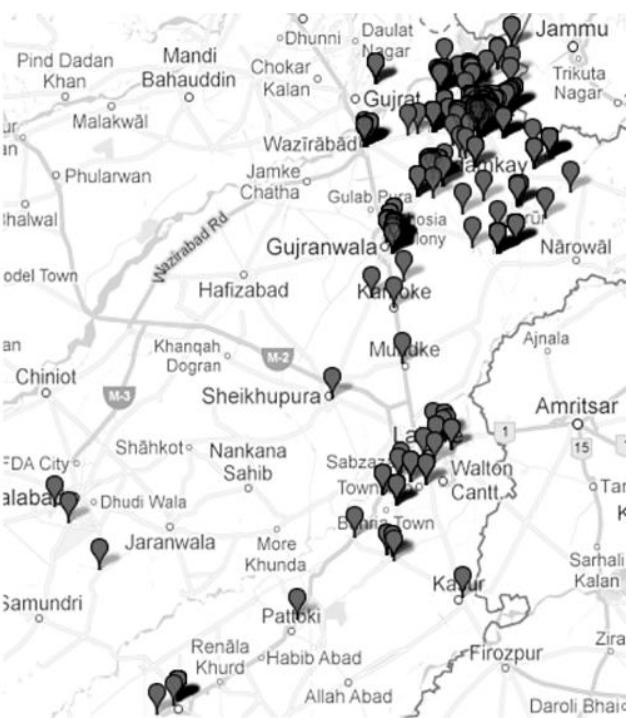


Figure 3: Sports goods

Figure 4: Iron and steel

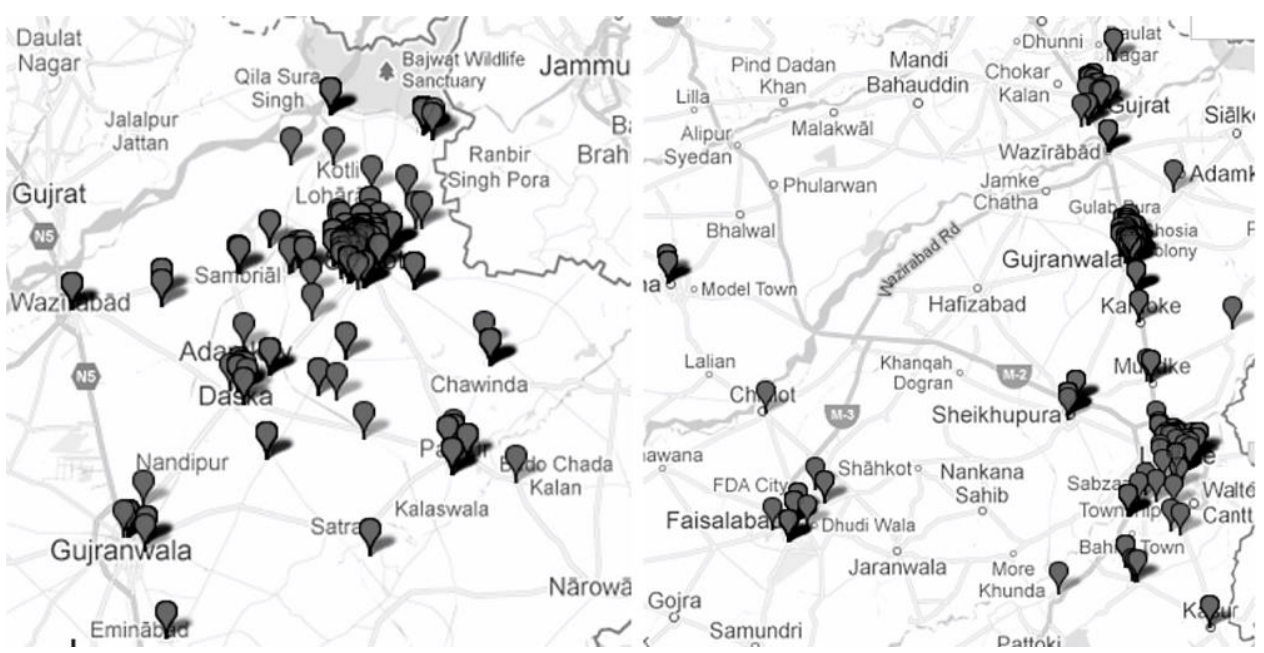

Source: Based on data from Government of the Punjab, Directory of Industries for 2010.

Figures 5-8: Examples of dispersed industries

Figure 5: Sugar

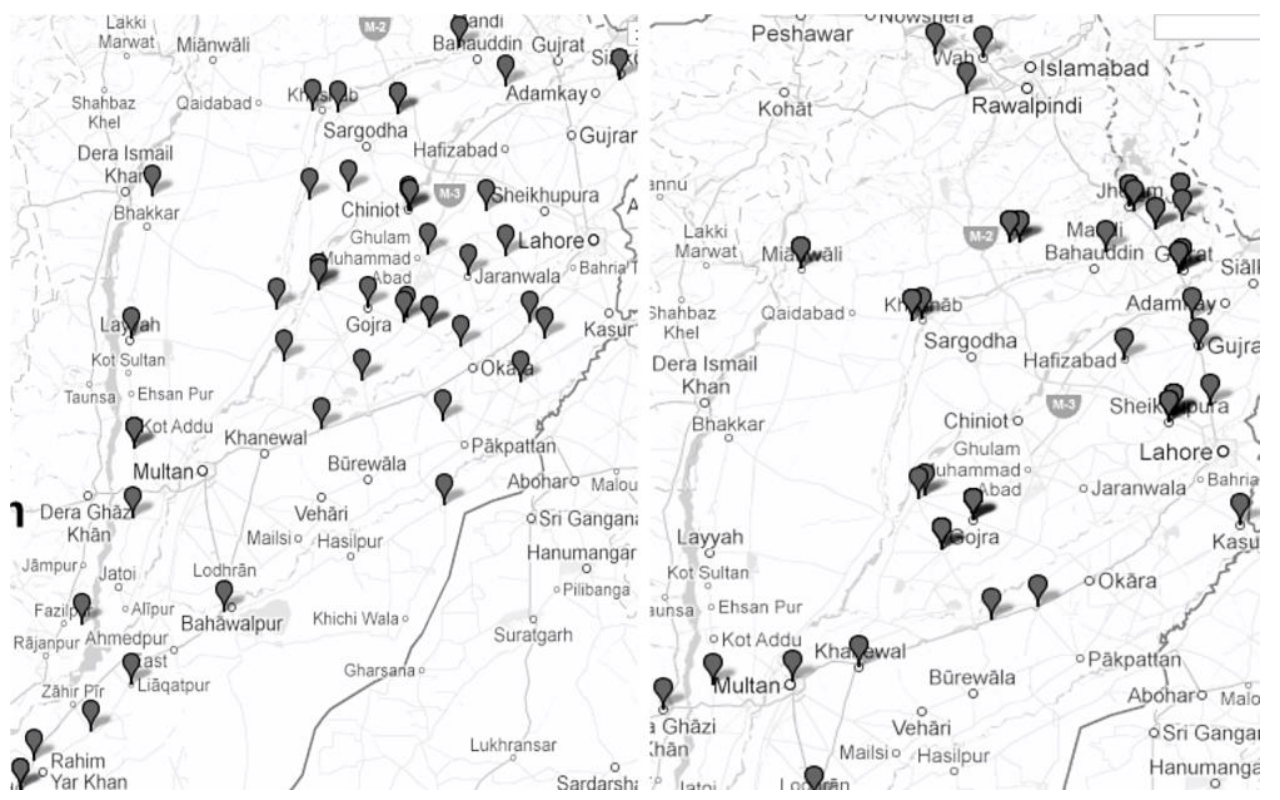

Figure 6: Cement 
Figure 7: Cotton

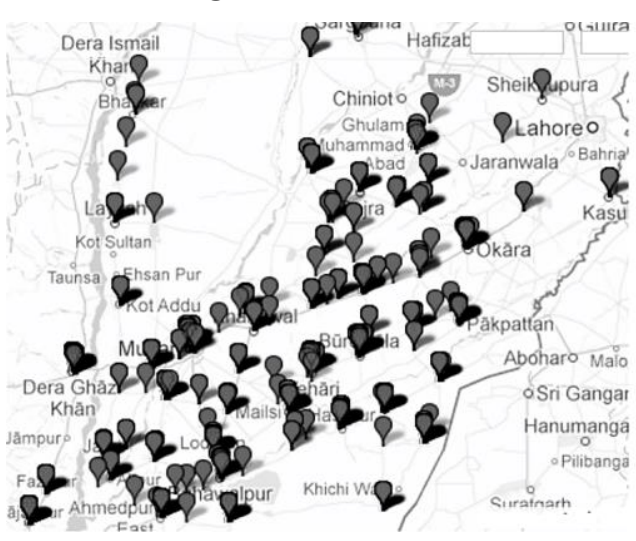

Figure 8: Rice

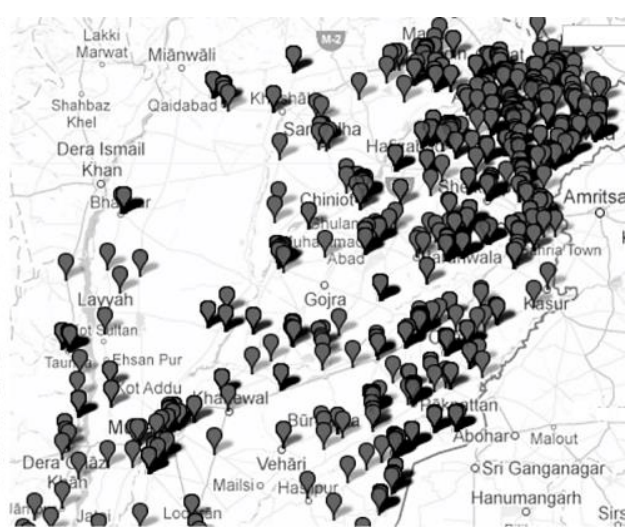

Source: Based on data from Government of the Punjab, Directory of Industries for 2010.

\section{Agglomeration, Firm Entry and Exit: An Econometric Model}

This paper's econometric model is designed to gauge the impact of agglomeration on firm entry and exit while controlling for other industry-level factors that affect entry and exit. Table 5 defines the variables used and indicates their hypothesized signs.

Table 5: Variables and definitions

\begin{tabular}{ll}
\hline Explanatory variable & \multicolumn{1}{c}{ Definition } \\
\hline EGI & $\begin{array}{l}\text { The EGI of agglomeration is constructed using firm } \\
\text { employment and consists of the Gini coefficient and } \\
\text { Herfindahl index. } \\
\text { The average age of a firm in an industry (how long } \\
\text { since it was established). } \\
\text { The average size of a firm in an industry, measured } \\
\text { by its number of employees. }\end{array}$ \\
Firm size & $\begin{array}{l}\text { The change in output during the study period. } \\
\text { The average initial investment of firms in an industry. }\end{array}$ \\
Sunk cost &
\end{tabular}

The model below, which is adapted from other studies on firm turnover and agglomeration, ${ }^{1}$ estimates the entry of new firms and the exit of existing ones against the agglomeration index while controlling for other factors that affect firm entry and exit. This cross-sectional analysis includes all 180 industries in Punjab for 2005/06. The equation is as follows:

$$
E_{i}=\frac{N_{i}}{I_{i}}=\beta_{0}+\beta_{1} E G I_{i}+\beta_{2} X_{i}+\varepsilon_{i}
$$

1 See, for example, Devereux et al. (2004); Dumais et al. (2002); Carlton (1983). 
$E_{i}$ is the entry rate for industry $i$ and is equal to the number of new firms in industry $i$ in 2006 that did not exist in $2002\left(N_{i}\right)$, divided by the total number of firms in industry $i$ in $2006\left(I_{i}\right) . E G I_{i}$ is the agglomeration index for industry $i$ in 2002 and $X$ is a vector of control variables, including average firm size, average firm age, average sunk cost and output growth. To measure the entry rate, we compare the datasets for two years, where firms listed in the 2006 dataset but not in the 2002 dataset are considered new entrants. The subscript $i$ refers to the 180 industries that comprise Punjab's manufacturing sector.

$$
Z_{i}=\frac{M_{i}}{F_{i}}=\beta_{0}+\beta_{1} E G I_{i}+\beta_{2} X_{i}+\varepsilon_{i}
$$

$Z_{i}$ is the exit rate for industry $i$ and is equal to the number of firms in industry $i$ in 2002 that did not exist in $2006\left(M_{i}\right)$, divided by the total number of firms in industry $i$ in $2002\left(F_{i}\right) . E G I_{i}$ is the agglomeration index for industry $i$ in 2002 and $X$ is a vector of control variables, including firm size, firm age, sunk cost and output growth. The exit rate is determined by comparing the two datasets: firms listed in the 2002 dataset but not in the 2006 dataset are considered to have exited the industry. The exit rate, therefore, represents those firms that have exited the industry as a proportion of the total firms in that industry in 2002.

Among the vector of control variables for both regression equations above, average firm size is measured using the employment data for the industry; firm age is based on the year in which it was set up. The output growth variable measures the change in output for the industry between 2002 and 2006. The higher the value of the EGI index, the more concentrated the industry is likely to be. The index for an industry $i$ is:

$$
E G I_{i}=\gamma_{i}=\frac{G-\left(1-\sum_{j} X_{j}^{2}\right) H_{i}}{\left(1-\sum_{j} X_{j}^{2}\right)\left(1-H_{i}\right)}
$$

$G$ is the Gini coefficient, denoted by $\sum_{j}\left(S_{i j}-X_{j}\right)^{2} . X_{j}$ is the share of employment for district $j$ relative to total employment in Punjab. $S_{i j}$ is the share of employment for district $j$ in industry $i$ relative to total employment in industry $i$ in Punjab. $H_{i}$ is the Herfindahl index for industry $i$, denoted by $\sum_{k} Z_{k}^{2}$ and $Z_{k}$ is the $k$ th firm's share of industry employment.

Both the Gini coefficient $(G)$ and Herfindahl index $(H)$ are useful measures per se. While the Gini coefficient measures income inequality 
across a population, as part of the EGI $(\gamma)$ it represents raw geographical concentration. The equations above show that it has a positive impact on agglomeration: a rise in $G$ will lead to a rise in $\gamma$. Intuitively, the more firms that are set up in a locale, the more agglomerated that industry is likely to be. The Herfindahl index is a measure of industry concentration and a rough indicator of the industry's market structure. It is negatively related to the agglomeration index according to the specification above, implying that a higher value of $H$ is obtained when there are fewer firms in the industry. This translates into lower agglomeration. Conversely, a lower value of $H$ is associated with a larger number of firms in the industry and thus with greater agglomeration.

\section{Results and Discussion}

This section uses ordinary least squares (OLS robust regression) to calculate the regression coefficients in both the entry and exit analyses.

\subsection{Estimates of Firm Entry, Exit and Agglomeration}

The study's estimates of firm entry and exit rates in Punjab's manufacturing sector from 2002 to 2006, as affected by agglomeration, imply that spillover benefits arise from geographical and industrial concentration. The results support the argument put forward by the literature: that agglomeration has a significant impact on firms' entry and exit rates and that the two are likely to be correlated. ${ }^{2}$

Firms tend to locate near similar units or in clusters to take advantage of spillovers in the form of access to technology, knowledge sharing and a labor supply with the required skills. The results also suggest that exit rates are higher in the more agglomerated industries: in the face of intense competition among firms, weaker firms find it difficult to survive as the incumbent firms start taking advantage of higher spillover benefits.

Table 6 presents the OLS results of the entry agglomeration and exit agglomeration analysis. The first two columns give the firm entry and agglomeration analysis coefficients, where column 2 controls for the effects of large industries (in terms of size) by incorporating industry dummies (excluded in column 1). A large industries dummy was created for those sectors with a large number of firms e.g. cotton industry with

\footnotetext{
2 See Devereux et al. (2004); Dumais et al. (2002); Carlton (1983); Rosenthal and Strange
} (2010); De Silva and McComb (2011) as discussed in Section 2. 
over 1300 firms and rice industry with over 1700 firms to incorporate industry shocks. ${ }^{3}$ The firm entry variable is the ratio of new firms (that entered the industry between 2002 and 2006) to the total number of firms in 2006. As shown in column 2, the EGI is positive and significant, implying that more firms will enter highly agglomerated industries than those that are dispersed, holding other industry factors constant.

Table 6: Regression results for entry agglomeration and exit agglomeration

\begin{tabular}{lcccc}
\hline \multirow{2}{*}{ Variable } & \multicolumn{2}{c}{ Entry } & \multicolumn{2}{c}{ Exit } \\
\cline { 2 - 5 } & $\mathbf{( 1 )}$ & $\mathbf{( 2 )}$ & $\mathbf{( 3 )}$ & $\mathbf{( 4 )}$ \\
\hline EGI & 0.007 & $0.016^{* *}$ & -0.015 & $0.036^{* *}$ \\
Output growth & $(0.0089)$ & $(0.006)$ & $(0.026)$ & $(0.018)$ \\
& 0.003 & $0.009^{* * *}$ & 0.002 & -0.005 \\
Firm age & $(0.0023)$ & $(0.002)$ & $(0.007)$ & $(0.005)$ \\
& $-0.003^{* * *}$ & $-0.001^{*}$ & 0.002 & $0.003^{* * *}$ \\
High cost (dummy =1 if sunk & $(0.0007)$ & $(0.003)$ & $(0.001)$ & $(0.001)$ \\
cost > PRs50 m) & 0.002 & 0.036 & 0.027 & 0.028 \\
Firm size: small (dummy $=1$ if & $(0.0219)$ & $(0.022)$ & $(0.063)$ & $(0.066)$ \\
$<49$ employees) & -0.011 & -0.002 & 0.083 & -0.028 \\
Firm size: medium (dummy $=1$ & $(0.024)$ & $(0.024)$ & $(0.068)$ & $(0.072)$ \\
if $\geq 49$ \& $<100$ employees) & 0.030 & 0.015 & 0.064 & -0.085 \\
Firm size: large (dummy $=1$ if & $(0.026)$ & $(0.025)$ & $(0.074)$ & $(0.072)$ \\
$\geq 100$ employees) & - & - & - & - \\
Large industries dummy & & & & \\
Cons. & $\mathrm{No}$ & Yes & $\mathrm{No}$ & Yes \\
\hline N & $0.129^{* * *}$ & $0.044^{*}$ & $0.118^{*}$ & 0.081 \\
$\mathrm{R}^{2}$ & $(0.026)$ & $(0.024)$ & $(0.070)$ & $(0.070)$ \\
\hline
\end{tabular}

Note: ${ }^{* * *}=$ statistically significant at the 1 percent level, ${ }^{* *}=$ statistically significant at the 5 percent level, ${ }^{*}=$ statistically significant at the 10 percent level. Robust standard errors given in parentheses.

Source: Author's calculations.

The exit agglomeration results are also separated into those without and with industry dummies in columns 3 and 4 , respectively. The exit rate is the ratio of firms that were operational in 2002 but not in

3 Other large industries include surgical instruments, sports, tanneries, hosiery, foundry, flour, cold storage, auto-parts and agricultural implements. 
2006 to the total number of firms in 2002. Column 4 shows that firm exit is positively influenced by the EGI, confirming that units are more likely to shut down in highly agglomerated industries.

This finding can be interpreted further by considering the impact of the EGI's components: the Gini coefficient and the Herfindahl index. Since both measure the concentration of firms, the more firms present either geographically or within an industry, the more competitive it is likely to be, thus making it difficult for existing firms to survive. If firms associate highly agglomerated industries with greater spillover benefits, then intuitively the latter will attract more entrants. However, these may also include weaker firms, which would have a higher probability of exiting the industry.

Among the control factors, output growth has a direct impact on the entry of new firms - this result holds only when the large industries dummy is controlled for. Industries with higher output growth will be more attractive to new firms hoping to achieve higher output and, in turn, higher profits. Another factor with a significant impact on firm entry is firm age, which has a negative impact on firm entry and a positive one on firm exit. The higher the number of older firms in an industry, the less likely new firms will enter or the more likely firms will exit, holding other factors constant. Older, more established firms tend to have stronger networks and the advantage of customer loyalty, thus creating barriers to entry for new firms or making it difficult for weaker firms to survive. Finally, the results show that the high cost and firm size variables have no significant impact on either entry or exit, although other studies have found them to affect firm entry and exit significantly.

\subsection{Data Limitations and Avenues for Further Research}

Since the Directory of Industries for Punjab is not published annually, the entry and exit analysis was restricted to five-year-interval (rather than annual) estimations. Any inaccurate records of firm names and addresses introduces the possibility of understating or overstating entry and exit rates (the names of some firms may have been spelled differently across datasets, thus affecting their likelihood of being included as an entrant or exiting firm). This problem was minimized by matching each firm to its year of establishment. The lack of information on firm sales, use of technology and leverage also limits the use of control variables in the estimations. Finally, this paper only incorporates 
industries in Punjab and could be extended to other provinces if similar data were available.

\section{Conclusion}

This paper contributes to the industrial organization literature on Pakistan by looking at the domestic factors affecting firm turnover in Punjab. New firms are attracted to industries characterized by agglomeration economies in the form of human and capital spillover benefits. Furthermore, firm entry tends to occur in industries with higher rates of output growth because this gives new establishments the chance to grow. The results also suggest that new firms are hesitant to enter industries dominated by older firms, which may prevent entrants from building a larger market share. The exit rate is also higher in such industries as weaker firms find it more difficult to survive.

The study provides some insight into industrial policies on promoting clusters where firms are highly integrated and resource and technological flows help them improve their productivity and growth. Industries are more likely to grow together while promoting competition among firms if they are more agglomerated. 


\section{References}

Burki, A. A, \& Khan, M. A. (2010, December). Spatial inequality and geographic concentration of manufacturing industries in Pakistan. Paper presented at the 26th Annual General Meeting and Conference of the Pakistan Society of Development Economists, Islamabad.

Carlton, D. W. (1983). The location and employment choices of new firms: An econometric model with discrete and continuous endogenous variables. Review of Economics and Statistics, 65(3), 440-449.

De Silva, D. G., \& McComb, R. P. (2011). Geographical concentration and firm survival (Working Paper No. 32906). Munich, Germany: University Library of Munich.

Devereux, M. P., Griffith, R., \& Simpson, H. (2004). The geographic distribution of production activity in the UK. Regional Science and Urban Economics, 34(5), 533-564.

Dumais, G., Ellison, G., \& Glaeser, E. L. (2002). Geographic concentration as a dynamic process. Review of Economics and Statistics, 84(2), 193-204.

Ellison, G., \& Glaeser, E. L. (1997). Geographic concentration in US manufacturing industries: A dartboard approach. Journal of Political Economy, 105(51), 889-927.

Fritsch, M., \& Mueller, P. (2004). The effects of new business formation on regional development over time. Regional Studies, 38(8), 961-976.

Hopenhayn, H. A. (1992). Entry, exit and firm dynamics in long-run equilibrium. Econometrica, 60(5), 1127-1150.

Marshall, A. (1920). Principles of economics (8 $8^{\text {th }}$ ed.). London: Macmillan.

Porter, M. E. (2000). Locations, clusters, and company strategy. In G. L. Clark, M. P. Feldman \& M. S. Gertler (Eds.), The Oxford handbook of economic geography (pp. 253-274). Oxford: Oxford University Press.

Roberts, B. M., \& Thompson, S. (2003). Entry and exit in a transition economy: The case of Poland. Review of Industrial Organization, 22(3), 225-243. 
Rosenthal, S. S., \& Strange, W. C. (2010). Small establishments/big effects: Agglomeration, industrial organization and entrepreneurship. In E. Glaeser (Ed.), Agglomeration economics (pp. 277-302). Chicago, IL: University of Chicago Press.

Soubeyran, A., \& Thisse, J. F. (1998). Learning-by-doing and the development of industrial districts. Journal of Urban Economics, 45(1), 156-176. 